\title{
DISTANCE LEARNING IN THE AGE OF COVID - 19: BETWEEN PERSPECTIVE AND REALITY
}

\author{
Oussama Dardary $^{1}$, Jabran Daaif ${ }^{1}$, Malika Tridane ${ }^{1,2}$, Said Belaaouad $^{1}$ \\ ${ }^{1}$ Laboratory of Physical Chemistry of Materials LPCM, Ben M'Sick Faculty of Sciences, P. B. 7955. Bd. Driss El \\ Harti. Hassan II University of Casablanca. Morocco. \\ ${ }^{2}$ Regional Center for Education and Training Casablanca Anfa, Bd BirAnzarane Casablanca. Morocco.
}

\begin{abstract}
Following the new global Coronavirus pandemic (COVID-19), Morocco has turned towards the use of "Distance Teaching - Learning" as an inevitable solution to ensure the continuity of learning and for the safety of the various educational actors. We followed a descriptive, analytical and exploratory method, through a qualitativequantitative approach. This situation has revealed the existence of hidden digital differences that hinder equal opportunities for all learners in equitable access to digital resources, which is reproduced in the school field, and calls into question the quality of this "Distance - Teaching". Not to mention the psychological impact of isolation and the fear of contagion.
\end{abstract}

The objective of our work is to pinpoint the difficulties, failures and successes of this change in school, through the integration of digital tools in teaching, and their effects on teachers and learners.

Keywords - ICT, Distance teaching - learning, digital equality, Morocco

\section{INTRODUCTION}

The school has been undergoing - for decades - a transformation following the massification and heterogeneity of the student population. This change is taking place under the effect of globalized economic and technological development which requires, for its dynamics, the updating, adaptation and development of new skills. The National Charter for Education supported the need for the integration of ICT for the first time in 1999 (V. Llorent-Bedmar, 2014) [1] \& (NEC, Lever 10) [2].

Today we are living through a revolution, a radical transformation in information and communication technologies that evolve and diversify every day, becoming more and more dependent on these new technologies and their uses. Among the consequences of this revolution is perhaps the emergence of a new generation of communication technologies, the Internet, computers, smartphones and electronic screens ... [3] which has brought us face to face with a new inevitable reality, adaptation seems the best solution, especially since the education system finds itself overnight in a situation which requires the use of ICT in the teaching - learning process, at the time of the pandemic, Coronavirus (COVID - 19). The school, therefore, underwent a metamorphosis during and after this period, thus teachers and students faced a huge challenge to ensure the continuity of the educational process. This situation has also imposed new challenges, in particular in the fields of politics, economy and education.

The role of ICT was tested through the preventive measures established by the state during the period of sanitary confinement as part of the fight against the possible spread of the COVID-19 virus, the ministry of national education, professional training, higher education and scientific research has announced the suspension of all courses from Monday March 16, 2020 [4], from kindergartens to higher education for the public, private and mission, and that students can follow their training from home (in order to allow students to continue their studies while staying at home) via television on the TV channel «Athaqafia » or via platforms established by the MEN such as: «TelmidTICE.men.gov.ma » without a password, and will provide lessons grouped according to subject, level and branch of study such as: «Teams », for the digital learning space Massar, which aims to meet the needs for improving and optimizing the information system in order to offer broad coverage of the new needs of the ministry, by integrating digital work and distance learning spaces, by management of learning and assessment of prior learning and by responding to new technical requirements through an information system oriented and improved for the different users of the system: Teachers, inspectors, counselors, students and parents [5]. Higher education students can also follow their studies on platforms offered by their universities/institutions or on the websites of faculties, centers, or institutions to ensure continuity of training, by providing sufficient digital and audiovisual resources and didactic kits for the needs of distance education and training for learners and to preserve the health of educational actors and of society.

Morocco has turned to distance education as an alternative solution to the spread of the global COVID - 19 virus, to allow learners to continue their learning under suitable conditions. 


\section{International Journal of Engineering Applied Sciences and Technology, 2020 \\ Vol. 5, Issue 6, ISSN No. 2455-2143, Pages 12-18 \\ Published Online October 2020 in IJEAST (http://www.ijeast.com)}

This has revealed the existence of hidden digital differences that hinder equal opportunities for all learners in equitable access to digital resources; this digital inequality is reproduced in the school field [3]. Not to mention the psychological impact of isolation and the fear of contagion.

This reality has led us to investigate the conditions of use of ICT, how the whole process unfolds, the percentages of the various interferants, as well as their opinions about distance education. This necessarily imposes the urgency of reformulating educational policy in Morocco on the principle of digital equity as an approach to educational justice, support and psychological accompaniment.

\section{PROBLEM}

The use of digital tools can also lead to a form of digital incivility (Boudokhane-Lima, Vigouroux-Zugasti \& Felio, 2019) [6] towards teachers or a problem of addiction in the student population (Kim \& Koh, 2018) [7].

So what are the effects of digital tools on attention management and on the quality of interactions in the educational relationship? What are the roles of social networks in educational situations? Is it a new dynamic in interactions between students? What are the effects of the use of social networks on the skills development of learners in a learning situation? This research focuses on the mastery of the digital tool, the use and support/training in ICT against COVID-19, through the response to specific questions.

- How to think, analyze and understand these logics of autonomous appropriation of digital tools, the construction of these private educational spaces by and for students?

- How to digitally rethink training over the good and bad experiences of confinement?

- How to understand the issue of equal access to knowledge mediated by ICT?

- In the current and future situation, how should we think about pedagogical, academic continuity vs. discontinuity?

- How to capitalize on the experiences of distance learning after the passage COVID - 19?

- What design of resource engineering and / or enriched or hybrid face-to-face training?

- What impact will it have on learners?

\section{THEORETICAL FRAMEWORK}

Online courses are those in which at least $80 \%$ of the course content is delivered online. Face-to-face instruction includes courses in which $0-29 \%$ of the content is delivered online; this category includes traditional and web-based courses. The other alternative, blended (sometimes referred to as hybrid) instruction is defined as having between $30 \%$ and $80 \%$ of the course content delivered online (Rickard, 2010). Mixed-mode instruction uses both online and face-to-face learning formats ideally combining the best elements of online and face-to-face learning (The Sloan consortium. 2008) [8].

The Integrated Post secondary Education Data System (IPDS) of National Center for Education Statistics (NCES) has defined a distance education program as a program for which all of the courses required for program completion can be taken through distance learning courses (Miller, Topper \& Richardson, 2017) [9] ; and considered a distance education course as " a course in which the educational content is provided exclusively by distance education " (Miller \& al., 2017 , p. 11). Distance education is generally defined as learning where teachers and students are separated either by time and / or geographic space, with some definitions also specifying that this separation is bridged through the use of technology. (Casey, 2008; Lease \& Brown, 2009; Lee, 2017; Moore, Dickson-Deane \& Galyen, 2010; Simonson, Schlosser \& Orellana, 2011).

The students form a network of exchange and sharing, they work together on their exercises, homework or presentations, and develop informal uses, in particular on social networks $(\mathrm{H}$. Soukrate, 2017) [10]. The learners exchange their notes, discuss among themselves, solve problems, communicate, collaborate or create. All this allows us to say that there is a use in (a good sense) of new information and communication technologies in education by learners. We can also talk about a group identity among the students (They form groups to share information or documents and discuss on social networks: Twitter, Myspace, Facebook, etc; or on mobile communication applications : WhatsApp, Messenger, Gmail ...), They use collaborative work tools (Google Docs, Google Drive, Dropbox, etc.). "Learn differently" in the digital age, train, collaborate, and innovate (J.M. Fourgous, 2012) [11].

However, some surveys indicate that access to ICT allows students to continue learning, they also claim that ICT can be a source of harmful distraction (Gaudreau, Miranda \& Gareau, 2014) [12], due to the double task induced by the use of these tools. The works of Junco (2012) [13] have shown that consulting (Facebook, twitter, etc.) during a course negatively affects the results obtained. 


\section{International Journal of Engineering Applied Sciences and Technology, 2020 \\ Vol. 5, Issue 6, ISSN No. 2455-2143, Pages 12-18 \\ Published Online October 2020 in IJEAST (http://www.ijeast.com)}

\section{METHODOLOGY}

To carry out this study, a survey was carried out "remotely" on social networks, following the confinement rules "Social distancing and confinement".

We followed a descriptive, analytical and exploratory method, since the researcher's position is a pragmatic position "which aims to produce something tangible", to answer questions about the use of ICT and "E-learning", with: teachers and learners, to determine the impact of this choice / solution on the various educational, administrative or technical actors and on the other hand by the students themselves.

The qualitative and quantitative approaches complement each other, one in the stability of these statistical indicators and the other in the description of facts and observations. A qualitative approach is not sufficient or unable to achieve these objectives, without being rejected. Our approach was qualitative-quantitative, through the selection of tools.

For the collection of information relating to the topic of our research, we have used social networks to contact the target population, through questions, some of which are closed and others are open.

The population targeted by our study is made up of 200 teachers and 100 primary-level learners, 100 middle school students and 100 high school students, distributed in the various provincial directorates of the region of Casablanca Settat.

The research aims for clear answers on the fundamental axes object of the investigation.

- Psychological impact

- Continuity of learning

- Continuity of education/training

- Access to the internet and the use of digital tools;

- Importance of the use of ICT;

- The conditions of ICT's use, according to learners and teachers;

- Learners' ICT skills;

- Participation of learners in distance education;

- Constraints related to the use of ICT.

\section{RESULTS AND DISCUSSION}

The data collected from the questions and the information accumulated during our investigation are classified and entered in the form of tables and graphs. Processing was performed by Microsoft Excel.

\section{A. Target POPULATION}

The population targeted by our study includes teachers and learners from both cycles: primary and secondary.

\section{B. Participation rate in "Distance learning"}
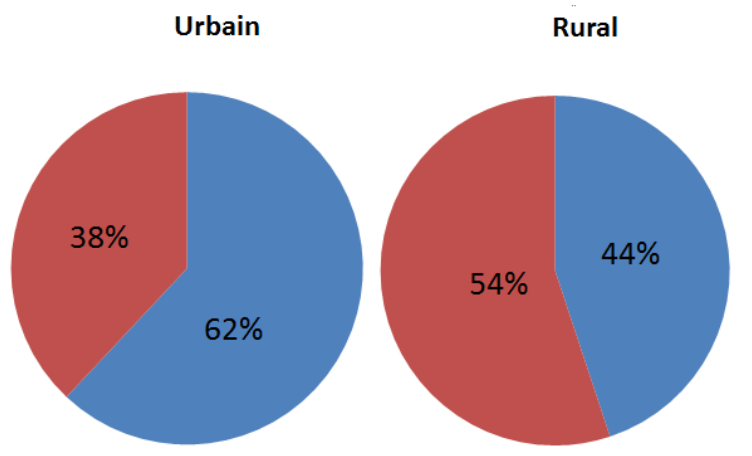

- Yes

Fig. 1. Percentage of learner participation in distance education in urban and rural areas

The previous figure shows that the participation of learners in distance education is higher in the urban setting $(62 \%)$, the participation rate is much higher $(89 \%$ in urban areas and $75 \%$ in rural areas) for learners of the first and second year of the baccalaureate; this is due to the exams at the end of the school year. However, the participation rate in distance education in some rural areas is less than $30 \%$ for other school levels.

\section{School program advancement / completion rate}

Most of the teachers were able to cope with the changes in the teaching and learning process and overcame the obstacle of distance and were able to complete the program, especially for the first and second year of the baccalaureate. Although the Ministry of National Education, Professional Training, Higher Education and Scientific Research has reported that the subjects of the exams will be limited to lessons completed in attendance before the suspension of studies.

"Regarding the remaining operations of the current school
year, in particular exams, the ministry has indicated that they
will be organized according to a specific schedule. Indeed, at
the level of the national education sector, only the
organization of the baccalaureate exam will be face-to-face,
and the subjects of this exam will be limited to the lessons
completed in presence before the suspension of studies, to
ensure the principle of equal opportunities, and the issuance
of a frame of reference defining the lessons in which
candidates will be examined.. "MEN-May 2020. [14]

\section{Internet access rate}

According to the National Telecommunications Regulatory Agency - NTRA, this year, both the Internet and mobile subscribers have experienced positive growth. Thus, the number of Internet subscribers has remained stable during this year, at 25.38 million subscribers, with an annual increase of $11.43 \%$ (against $2.6 \%$ in 2018) and a penetration rate of 71.33\%. Among mobile internet subscribers, the annual 


\section{International Journal of Engineering Applied Sciences and Technology, 2020 \\ Vol. 5, Issue 6, ISSN No. 2455-2143, Pages 12-18 \\ Published Online October 2020 in IJEAST (http://www.ijeast.com)}

growth rate reached $11.22 \%$ (compared to $2.21 \%$ in 2018), reaching 23.68 million subscribers. In turn, the share of subscribers in the fourth generation telecommunications service reached 15.72 million subscribers, an annual increase of $63.66 \%$, compared to $40.61 \%$ in 2018 [15].

As for "ADSL" fixed Internet subscribers, they reached 1.47 million subscribers by the end of 2019, recording a growth rate of $4.07 \%$ over the year. In addition, the number of fiberoptic Internet (FTTH - Fiber To The Home) subscribers reached 121273 at the end of 2019, compared to 73169 in the previous year [15].

Towards the end of December 2019, the international bandwidth of the Internet increased, with an annual growth rate of $30.61 \%$ at $1970 \mathrm{~GB}$ [15].

Regarding usage, monthly voice traffic from the mobile for each subscriber increased by $3 \%$ between the end of 2018 and the end of 2019, going from 100 minutes per month to 103 minutes per month. An annual decrease of $5.97 \%$ was recorded for the prepaid service, the utilization rate reaching 63 minutes per month, at the end of December 2019, while this rate increasing, for the service with subsequent performances, from 477 minutes per month to 480 minutes per month, during the same period [15].

In terms of information security, - Internet users aged 24 represent approximately $76 \%$ of Internet users who do not protect themselves against threats and malicious software "Cyberattack", because they are still unaware of the existence of protection tools [16].

\section{E. Impact of the pandemic}

\section{Psychological impact}

According to the presentation by the Minister of Education, on the 2020 baccalaureate exam, to the Government Council on June 18, 2020:

- The total number of candidates was: 441238,318 917 among them are educated and 122321 are free "free baccalaureate" (28\%). Girls represent $49 \%$ of all applicants.

- The candidates are divided according to the specialties/path in the following form: scientific and technical path 249 338, literary and authentic path 181234 and professional path 10666 candidate(s).

All these students (with those from universities, centers, primary, etc.) remained confined to their homes for two months and received a three-week extension. Anxiety, depression, stress and fear of others. What were the psychological effects of confinement and isolation on learners?

An exceptional experience which is not without consequences. Several factors can change the way we react to this situation, positively or negatively. A meta-analysis that has just appeared in the Lancet [17] shows that this experience can, for example, have a deleterious psychological impact, with mood disorders, confusion, and even post-traumatic stress disorder. The risk of these manifestations increasing with the length of isolation, but also with other factors such as housing conditions, loss of income, lack of information, or boredom. In Morocco The PHC investigation [18] (Planning High Commission) makes it possible to measure the extent of the damage / psychological impacts of confinement on the Moroccan population:

* Anxiety: (49\%) of households: This proportion reaches (54\%) among households residing in slums, against (41\%) among those in modern housing.

* Fear: felt by (41\%) of Moroccan households, among poor households (43\%), against 33\% among the welloff.

Table -1 Psychological impact in urban and rural areas

\begin{tabular}{cccc}
\hline Psychological impact & Percentage & Urbain & Rural \\
\hline $\begin{array}{c}\text { The deterioration of } \\
\text { family relations }\end{array}$ & $18 \%$ & $20 \%$ & $12 \%$ \\
\hline Sleep disorders & $24 \%$ & $28 \%$ & $14 \%$ \\
\hline Phobias & $25 \%$ & $29 \%$ & $18 \%$ \\
\hline $\begin{array}{c}\text { The feeling of } \\
\text { claustrophobia }\end{array}$ & $30 \%$ & $32 \%$ & $24 \%$ \\
\hline $\begin{array}{l}8 \% \text { of households have other psychological disorders } \\
\text { such as hypersensitivity } \\
\text { fatigue, etc. }\end{array}$ & and nervousness or \\
\hline
\end{tabular}

\section{Educational impact}

The World Bank released its report on the impact of the Corona pandemic on education, which was forced by sudden development and change, addressing the most significant transformations and imbalances education witnessed during the pandemic. They confirm that "education will not be the same" (after this pandemic). [19]

Among the consequences of this pandemic:

\section{- Closure of schools.}

During lockdown and state of emergency, school closures due to COVID-19 affected more than one billion students [20]. According to information currently collected by the World Bank, at the time of writing, 150 countries have already indicated that they have closed schools [21], [22]. These numbers have increased rapidly since the end of February. 


\section{International Journal of Engineering Applied Sciences and Technology, 2020 \\ Vol. 5, Issue 6, ISSN No. 2455-2143, Pages 12-18 \\ Published Online October 2020 in IJEAST (http://www.ijeast.com)}

- The school dropout rate will increase.

- $\quad$ Learning will suffer even more.

- On the supply side, economic shock will hit schools and teachers.

\section{$F$. Constraints related to the use of distance education}

Extrinsic constraints: problems related to access, time, support, resources and training.

- Lack of digital equipment;

- Lack of access to the internet at home;

- $\quad$ Lack of digital tools at home (tablet or computer);

- High price for internet access (10 MAD = $1 \mathrm{~GB})$;

- Lack of network (for some rural areas);

- Insufficient ICT training (Zoom, Teams, Google Meet, etc.);

Intrinsic obstacles: relating to individuals, practices and teacher resistance.

- $\quad$ Lack of confidence in "E-Learning";

- Lack of teacher-learner interactivity;

- Fear of appearing on the camera or talking on the phone;

- Fear of being hacked through mobile applications;

- Resistance to change;

- $\quad$ Lack of openness to IT;

This study has revealed the existence of hidden digital differences that hinder equal opportunities for all learners in equitable access to digital resources, which is reproduced in the school field, contrary to what is provided for in the national charter, which was established as an effective solution to the situation that the education sector had experienced difficulties in the past, it describes the new system as one based on equity, equality of opportunity and quality, which would promote individual and social progress [23].

\section{$G$. How to mitigate the impact of COVID - 19 in education}

Policies aimed at reversing the situation can be grouped into three overlapping phases: Adaptation, Management of Continuity and Improvement and Acceleration of Learning (see Figure 2) - (World Bank Report) [19].

Objective: Seize opportunities to make education more inclusive, effective and resilient than it was before the crisis.

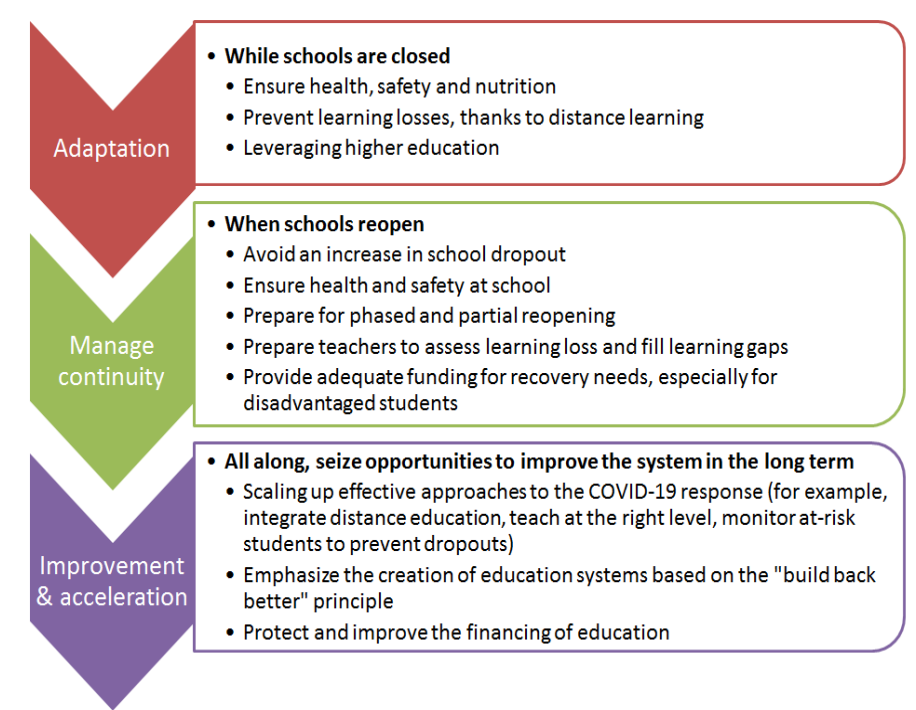

Fig. 2. The three overlapping phases of the education response - World Bank Report, May 2020

\section{$H$. Scenarios for the start of the next school year}

What strategy for the next school year? Three scenarios would be studied: a traditional start of the school year, an extension of distance learning courses or an alternation between classroom attendance and distance learning courses. The remote course scenario will be adopted, but "only in towns or districts declared as centers of large-scale contagion by the health authorities" [24]. The results of a comparative study carried out in Morocco by O. ALJ et al, (2016) [25], as well as other researches, including ours in the past few couple of years, O. DARDARY et al, (2018, 2019) [26], [27], [28], [29] in this subject reveal that the initiatives personal relationships can always make a difference and increase the number of potential adopters. However, initiatives can be institutionalized for a wider possible consideration of ICT in Moroccan schools.

\section{CONCLUSION}

Faced with this pandemic, the Ministry of National Education, Professional Training, Higher Education and Scientific Research affirmed that it had been decided to ensure the continuity of education through the process of "Distance learning", until the end of the current school year, for the benefit of learners, students and trainees. She stressed that this educational continuity comes to complement the academic courses and training programs and provide the educational support necessary for a good preparation for the exams, through various digital platforms, television channels and brochures that will be distributed to primary school students in remote areas of the rural center. 


\section{International Journal of Engineering Applied Sciences and Technology, 2020 \\ Vol. 5, Issue 6, ISSN No. 2455-2143, Pages 12-18 \\ Published Online October 2020 in IJEAST (http://www.ijeast.com)}

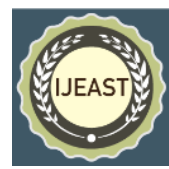

All education systems around the world are in emergency response mode. This is most appropriate given the sudden nature of this crisis. The immediate priority is to adapt to the situation, which means first ensuring health and safety, and then doing everything possible to maintain student participation, through distance education and training, and other digital means.

This situation has revealed the existence of hidden digital differences which hinder equal opportunities for all learners in equitable access to digital resources, which is reproduced in the school domain, and calls into question the quality of this "distance - teaching/learning", without forgetting the psychological impact of isolation and the fear of contagion.

To improve the situation, it is best to think about:

- Equip schools with video cameras, interactive whiteboards and a fast internet connection.

- Subscribe all students and teachers to Internet packages / subscriptions at reasonable costs and within the reach of learners.

- Provide psychological support to depressed learners / teachers.

- Provide training in ICT for learners as well as teachers.

But this transformation requires planning now. Even as systems adjust to school closures, they must begin to plan how to manage continuity when schools reopen and how to improve and accelerate learning. Vision and proactive action will not only help mitigate the negative effects of the current crisis but could also turn recovery into real growth, to seize this opportunity to reduce digital inequality and "build back is better." The challenge will therefore be to prepare for a safe return to school in healthy conditions conducive to the next phase of the confrontation of this epidemic.

\section{REFERENCE}

[1] Llorent-Bedmar, V. (2014), Educational Reforms in Morocco: Evolu-tion and Current Status - International Education Studies; Vol. 7, No. 12 - ISSN 1913-9020 EISSN 1913-9039 https://doi.org/10.5539/ies.v7n12p95.

[2] The national education and training charter, lever 10, article 121, M.E.N . Morocco.

[3] Echerkaoui, S. (2020), Distance learning in Moroccan experience under digital inequality. Revue de droit constitutionnel et sciences administratives, Volume 6, Avril.

[4] Ministerial announcement concerning the interruption of face-to-face courses and their replacement by distance courses. Please refer to the following link:
https://www.men.gov.ma/Ar/Pages/Publication.aspx?IDP ublication $=5938$

[5] Medias24. https://www.medias24.com/coronavirussuspension-des-cours-au-maroc-a-partir-du-lundi-16mars-8322.html. March 13, 2020. Modified March 15, 2020. Visited March 16, 2020.

[6] Boudokhane-Lima, F., Vigouroux-Zugasti, E., \& Felio, C. (2019). Incivilités numériques à l'université: les enseignants face aux pratiques estudiantines. Communication et organisation, (56), 77-91.

[7] Kim, E., \& Koh, E. (2018). Avoidant attachment and smartphone addiction in college students: The mediating effects of anxiety and self-esteem. Computers in Human Behavior, 84, 264-271.

[8] Wachira, P. (2020). Learning to Teach Mathematics Online: An Action Research Study. Handbook of Research on Online Pedagogical Models for Mathematics Teacher Education, DOI: 10.4018/978-1-7998-14764.ch014.

[9] Miller, A., Topper, A. M., Richardson, S., Suggestions for improving IPEDS distance education data collection. (NPEC 2017). U.S. Department of Education. Washington, DC: National Postsecondary Education Cooperative. Retrieved [date] from http://nces.ed.gov/pubsearch.

[10] Soukrate H. (2017). Les difficultés des étudiants des facultés des sciences dans la compréhension des notions de la thermodynamique, (thesis).

[11] Fourgous, J.M. (2012). " Apprendre autrement » à l'ère numérique Se former, collaborer, innover : Un nouveau modèle éducatif pour une égalité des chances. Available on the file in the following link: https://www.acstrasbourg.fr/fileadmin/pedagogie/eps/FTP_Num/Context e_institutionnel_-

_Numerique_et_innovation_pedgogique_a_1_ecole.pdf.

Last accessed 14.01.2020 - p.160

[12] Gaudreau, P., Miranda, D. \& Gareau, A. (2014). Canadian university students in wireless classrooms: What do they do on their laptops and does it really matter? Computers \& Education, 70, 245-255. doi :10.1016/j.compedu.2013.08.019.

[13] Junco, R. (2012). In-class multitasking and academic performance. Computers in Human Behavior, 28(6), 2236-2243. doi:10.1016/j.chb.2012.06.031.

[14] ASSAHARAA Journal, 2020. https://assahraa.ma/web/2020/148982. Accessed May 24, 2020.

[15] Announcement from the National Telecommunications Regulatory Agency - NTRA. March 6, 2020. https://www.anrt.ma/sites/default/files/document/cp-tb2019-t4-ar.pdf. Accessed July 16, 2020. 
[16] Annual field research into information and communication technology equipment and uses, National Transport Regulatory Agency, 2017, p. 17-18. Accessed July 16 , 2020.https://www.anrt.ma/sites/default/files/rapportannue 1/rapport_annuel_2017_va.pdf

[17] Brooks, K. B., \& al (2020). The psychological impact of quarantine and how to reduce it: rapid review of the evidence. Le 26 Novembre, The LANCET. https://doi.org/10.1016/S0140-6736(20)30460-8.

[18] Ecoactu.ma (2020). COVID-19 : La Population Marocaine Souffre... Psychologiquement. May 21, 2020. Accessed July 16, 2020. https://www.ecoactu.ma/covid19-effets-psychologique/

[19] World Bank Report, 2020. Covid19 Pandemic: Education Shock and Policy Responses. May 2020. https://www.banquemondiale.org/fr/topic/education/publi cation/the-covid19-pandemic-shocks-to-education-andpolicy-responses

[20] UNESCO : Coronavirus Impacts Education https://en.unesco.org/themes/educationemergencies/coronavirus-school-closures

[21] Information gathered through productive participation of World Bank teams.

[22] Guidance Note on the Response of Education Systems to COVID19. March 25, 2020.

[23] Anastasia Pestova. Reforming Education: How Morocco Plans on Empowering the Next Generation. September 23 , 2015. https://moroccoonthemove.com/2015/09/23/reformingeducation-morocco-plans-empowering-next-generationanastasia-pestova/. Visited the 21 August 2020.

[24] https://www.lebrief.ma/7067-enseignement-troisscenarios-pour-la-reprise-en-septembre. Visited the 2nd September 2020.

[25] Alj, O., Benjelloun. N. (2016). Etude comparative des résultats de quelques recherches sur l'intégration des TIC dans l'enseignement des disciplines scientifiques au sein $\mathrm{du}$ programme GENIE Marocain, Valable sur : https://www.epi.asso.fr/revue/articles/a1601c.htm

[26] Dardary O., Azar Z., Tridane M., Belaaouad S. (2019). Engineering of a Training Device and Skills through the Integration of New Information and Communication Technologies in the Field of Exact Sciences. International Journal of Advanced Trends in Computer Science and Engineering Volume 8, No.1.4 (IJATCSE). DOI: https://doi.org/10.30534/ijatcse/2019/4581.42019

[27] Dardary O., Azar Z., Tridane M., Belaaouad S. (2019). Importance of using Simulation in Chemistry: the Case of Batteries, Accumulators and Electrolysis. International Journal of Recent Technology and Engineering (IJERT). Volume 8 issus 3. DOI: 10.35940/ijrte.C5148.098319
[28] Dardary O., Elmazouni N., Tridane M. Belaaouad S. (2019). The impact of the genie program on the integration of ICTs in Moroccan education and its effect on teachers. Journal of E - Technology. Volume 10, Number 4, November 2019. DOI: 10.6025/jet/2019/10/4/126-136

[29] Dardary O., Tridane M., Belaaouad S. (2018). Constraints related to the integration of information and communication technologies in the teaching of physical sciences at the Level of the Moroccan Educational System. Indian Journal of science and technology. Vol 11. (44), 1-15 (2018). $10.17485 / \mathrm{ijst} / 2018 / \mathrm{v} 11 \mathrm{i} 44 / 132138$ 